\title{
Sun-protection strategies amongst people living with Albinism in Benin-city, Southern Nigeria
}

\author{
*Madubuko C.R., Onunu A.N.
}

\begin{abstract}
Background: Oculocutaneous albinism (OCA) is an inherited disorder of generalized hypopigmentation. Dermatological care and protection from UV radiation are necessary for individuals with OCA. We assessed the patterns of protection strategies amongst persons living with albinism in Benin-city, Nigeria.
\end{abstract}

Methods: Snow ball sampling methods were employed to investigate sun protection strategies amongst albinos in UBTH, Benin-city, Nigeria. Avoidance of sun peak hours, sun-protection clothing and sunscreen preparations used were analyzed during semi-structured face to face interviews conducted in the outreach clinics.

Results: A total of 73 participants living with albinism were studied. The mean age of the participants was 24.1 years \pm 11.3 years. The predominant activity type was out-door occurring in $62(84.9 \%)$ of the population observed. Participants with albinism in this study were exposed to high levels of ultraviolet radiation throughout the year. They all reported being unable to avoid sun-peak hours. Sunscreens were used in $15(20.5 \%)$ albinos studied while sun-protection clothings were worn in 13(17.8\%) respondents. Sunscreens were used more in those who engaged principally in out-door activities. This was observed in $10(13.7 \%)$ clients studied $(p=0.04)$.

Conclusion: People leaving_with albinism who attended UBTH outreach skin clinic had insufficient sun protection strategies.

Keywords: Oculocutaneous albinism, sun-protection

*Corresponding author

Madubuko, C.R.

ORCID-NO: http://orcid.org/0000-0002-9155-4257

Email: rolimadubuko@yahoo.com

Department of Medicine, University of Benin Teaching Hospital, Benin City, Nigeria. 


\title{
Stratégies de protection solaire parmi les personnes atteintes d'albinisme à Benin-city, dans le sud du Nigeria
}

\author{
*Madubuko C.R., Onunu A.N.
}

\begin{abstract}
Resume
Contexte: L'albinisme oculocutané (OCA) est un trouble héréditaire de l'hypopigmentation généralisée. Des soins dermatologiques et une protection contre les rayons UV sont nécessaires pour les personnes atteintes d'OCA. Nous avons évalué les modèles de stratégies de protection parmi les personnes vivant avec l'albinisme à Benin-city, au Nigeria.
\end{abstract}

Méthodes: Des méthodes d'échantillonnage de boules de neige ont été utilisées pour étudier les stratégies de protection solaire chez les albinos à UBTH, Benin-city, Nigeria. L'évitement des heures de pointe du soleil, les vêtements de protection solaire et les préparations de crème solaire utilisées ont été analysés lors d'entretiens semi-structurés en face à face menés dans les cliniques de proximité.

Résultats: Un total de 73 participants vivant avec l'albinisme ont été étudiés. L'âge moyen des participants était de 24,1 ans $\pm 11,3$ ans. Le type d'activité prédominant était à l'extérieur chez $62(84,9 \%)$ de la population observée. Les participants atteints d'albinisme dans cette étude ont été exposés à des niveaux élevés de rayonnement ultraviolet tout au long de l'année. Ils ont tous déclaré être incapables d'éviter les heures de pointe du soleil. Des écrans solaires ont été utilisés chez $15(20,5 \%)$ albinos étudiés tandis que des vêtements de protection solaire ont été portés chez 13 (17,8\%) répondants. Les écrans solaires étaient davantage utilisés chez ceux qui se livraient principalement à des activités de plein air. Cela a été observé chez $10(13,7 \%)$ clients étudiés $(\mathrm{p}=0,04)$.

Conclusion: Les personnes atteintes d'albinisme qui ont fréquenté la clinique cutanée de proximité de l'UBTH avaient des stratégies de protection solaire insuffisantes.

Mots clés: Albinisme oculocutané, protection solaire

*Corresponding author

Madubuko, C.R.

ORCID-NO: http://orcid.org/0000-0002-9155-4257

Email: rolimadubuko@yahoo.com

Department of Medicine, University of Benin Teaching Hospital, Benin City, Nigeria. 


\section{INTRODUCTION}

Oculocutaneous albinism (OCA) is a congenital condition causing hypopigmentation of the hair, skin and eyes. Diagnosis in a black population is clear and unequivocal. Four different types of oculocutaneous albinism (OCA) have been described $(1,2)$. The most common are OCA -1 and OCA-2. OCA-2 is estimated to occur in high frequencies in subSaharan Africa, ranging from 1 in 1400 to 1 in 7000 (3). A similar high prevalence has also been reported, in northern South Africa where the frequency is 1 in 1500 (4) to 1 in 1900 among the black population (5).

The UV radiation especially in tropical areas has being associated with extreme skin damage in people living with albinism due to the lack of melaninization of their skin. Though melanocytes are present in them, they lack important enzymes like tyrosinase required for the production of melanin. Sun induced skin damage is a major health issue for these persons. They are highly susceptible to solar urticaria, photo-ageing of the skin, solar keratoses and carcinomas $(6,7)$. Skin cancers of the head and neck are the most common malignancies seen in African patients with albinism (8). Longer term chronic consequences included dermatoheliosis of the skin and solar elastosis (9).

In some studies, photo-induced dermatoses was found in those were were quite young (12 months of age) (10). It is well documented that non-melanoma skin cancers including basal and squamous cell malignancies, while rare in black populations (11), are common in persons living with albinism (12). These cancers increase morbidity and mortality, are disfiguring and expensive to treat. Studies in west, east and southern Africa reveal the extent of the vulnerability of those affected by albinism. In Nigeria, people as young as 20 years old living with albinism developed basal cell carcinomas (13) leading to a diminished life expectancy (14). Looking bill and colleagues found skin cancers in $25 \%$ of those aged over 20 years (15). The extreme susceptibility of those with albinism in Africa is thus well documented, with skin damage developing from a young age In this study we sought, to explore the use of sun protection strategies amongst persons living with albinism in Benin-city, Nigeria with intense tropical sun-shine.

\section{METHODOLOGY}

\section{Study area}

The study was carried out in the University of
Benin Teaching hospital through an albino outreach skin clinic.

\author{
Study design \\ This was a descriptive cross sectional \\ study.
}

\section{Study population}

All patients with albinism, presenting at the Dermatology Outreach Albino Clinics in the University of Teaching Hospital, Benin-city were included.

\section{Selection criteria}

Inclusion criteria for study population: All persons with oculocutaneous albinism consenting to the study, attending the albino outreach clinics

Exclusion criteria for study population: All persons without oculocutaneous albinism

\section{Ethical consideration}

Ethical clearance certificate was gotten from the Ethics and research committee of the University of Benin Teaching Hospital for the study. Informed consent was obtained directly from the adult study participants and from the parents or guardian of participants who were under aged.

\section{Sampling technique}

A snowball sampling technique was utilized where any client with albinism presenting at the clinic and who consented to study was encouraged to nominate another albino (17).

\section{Data management}

An interviewer administered questionnaire was used to extract information from each respondent. The questionnaire included information on socio-demographics such as age, sex, marital status, educational status, occupation, principal activity type (outdoor or indoor) and monthly income. Information on the use of sun-protection strategies was also included in the questionnaire.

\section{Data analysis}

All data collected were analyzed using statistical package for social sciences (SPSS) version 21.0. Results were presented in tabular form. Discrete variables were presented as frequency and percentages. Continuous variables were presented as mean and standard deviation. Chi square test was used to compare categorical variables. $\mathrm{P}<0.05$ was taken as significant 


\section{RESULTS}

A total of 73 respondents living with oculocutaneous albinism were recruited for the study. There was a female preponderance of $41(56.2 \%)$. The mean age for the participants was $24.1 \pm 11.3$.The age group that was mostly represented in the study was 21-30years age group accounting for $27(37 \%)$ of clients studied.

Most of the respondents were unemployed accounting for $43(58.9 \%)$ of the population. The predominant activity type observed in the study was out-door activities representing $62(84.9 \%)$ of the population. In terms of marital status, most of the respondents were single 63(86.3\%) see table1. All respondents admitted to being unable to avoid sun-peak hours. There were $15(20.5 \%)$ respondents who used sun-screens regularly as part of their daily routine $58(79.5 \%)$ did not use sunscreens as part of their daily routine. Thirteen $(17.8 \%)$ participants wore sun-protection clothing regularly while $60(82.2 \%)$ did not were sun-protection clothing. There was a female gender predilection for sunscreen use; $10(13.7 \%)$ vs $5(6.8 \%)$ for females and males respectively. $p>0.05$. There was a male gender predilection for sun-protection wears amongst the respondents; $8(11 \%)$ and $5(6.8 \%)$ for males and females respectively. $p>0.05$. Respondents in the 21 30 years age group were observed to use more of the sun-protection strategies; $7(9.6 \%)$ for sunprotection clothing and 9(12.3\%) for sunscreen use. These observations were not statistically significant in both. $p>0.05$

A majority of participants in this study, who used sun protection strategies had tertiary level of education; $10(13.7 \%)$ for sun protective wears and $12(16.4 \%)$ for sunscreen use. These observations were however not statistically significant. $p>0.05$. Sunscreens were used more by respondents who engaged in predominantly outdoor activities when compared to those who were primarily indoors most of the times $(10(13.7 \%)$ and $5(6.8 \%)$ respectively). This finding was statistically significant. $p=0.04$. Sun-protection wears were used more by respondents who engaged in predominantly outdoor activities when compared to those who were primarily indoors $(11(15.1 \%)$ and $2(2.7 \%)$ respectively). This finding was not statistically significant. $p>0.05$

\section{DISCUSSION}

Oculocutaneous albinism is an inherited disorder of pigmentation with no cure and requiring lifelong management. Dealing effectively with the medical and social issues encompassing albinism in low resource nations with limited funds is a problem. The World Health Organization sees albinism as a major public health problem throughout sub-Saharan Africa and is currently investigating this at-risk population (18). Taylor and Lund in their study done in Zimbabwe, documented not just the plight of families affected by albinism (19) but also highlighted the imaginative and effective self-management strategies that have been adopted with little or no access to specialist health care facilities or social welfare support (20).

All respondents in this study claimed they were unable to avoid sun-peak hours. The exposure to ultraviolet light appears to be the most important risk factor in the development of skin cancers in albinos (21). These cancers include basal cell carcinomas, squamous cell carcinomas and amelanotic melanomas. Squamous cell carcinoma is the most common skin cancers seen in albinos $(22,23)$. The major acute effects of UV irradiation on human skin comprise sunburn inflammation (erythema), and local or systemic immunosuppression. At the molecular level, UV irradiation causes DNA damage such as cyclobutane pyrimidine dimers and (6-4) photoproducts, which are repaired by nucleotide excision repair (NER). Chronic exposure to UV irradiation leads to photoaging, immunosuppression, and ultimately photocarcinogenesis (24). Absorption of UV in a cell leads to the production of reactive oxygen and nitrogen species that can cause damage to DNA and membrane lipids. Various types of damage induced in these molecules lead to significant biological effects including cytotoxicity, mutations and alterations in cell signaling pathways (24).

Sunscreen use was observed in only $20.5 \%$ of the respondents. Although sunscreens may reduce the effect of photo-related damage, they do not prevent photodermatoses, including a variety of molecular changes such as DNA damage and suppression of immune functions (25). Limiting sun exposure must be the key intervention to prevent these deleterious effects. Furthermore, light scattering in the atmosphere means that vulnerable people can still become sunburnt in the shade. Those with OCA should move indoors at times of peak UV intensity rather than merely seeking the shade. Sunscreens have traditionally been divided into chemical absorbers and physical blockers on the basis of their mechanism of action. Chemical sunscreens are generally aromatic compounds conjugated 
with a carbonyl group (26). These chemicals absorb high-intensity UV rays with excitation to a higher energy state. The energy lost results in conversion of the remaining energy into longer lower energy wavelengths which return to ground state. Inorganic particulate sunscreens, zinc oxide, and titanium dioxide, can reflect or scatter UVR. Arguably, a SPF 15 sunscreen provides full UV-B protection for healthy individuals. A SPF 15 product filters out more than $93 \%$ of UV-B radiation, and a SPF 30 product filters out less than $97 \%$. With the availability of higher SPF products allowing individuals to spend greater amounts of time in the sun without burning, concerns have been raised about the adequacy of the UV-A protection of these products. In fact, individuals relying on sunscreens as their sole form of photoprotection may now be subject to greater cumulative sun exposure, including UVA radiation (27).

Sun-protection clothing was used in just $17.8 \%$ of our study population. Clothing can be an excellent form of sun protection. The most important determinant is tightness of the weave. Fabric type is less important. Thickness is also less important than regular weave. Protection drops significantly when the fabric becomes wet. Color plays a minor role, with dark colors protecting better than light colors. A crude test of clothing is to hold it up to visible light and observe the penetration (26). Hats are the most important articles of clothing serving as a form of sun-protection. A 4-inch wide circumferential brim is required to cover the entire face and neck. Wearing a hat is a simple inexpensive photoprotective measure.

We discourage an instructive approach to information delivery by health workers and recommend an interactive, social approach for outreach programmes, with a directed attention on the management of albinism. People with albinism should be encouraged to deliver information on sun protection, as well as other aspects of albinism, as this may be more effective than obtaining the message from dark complexioned health care professionals who are deficient of direct experiences of living with an amelanotic skin in a tropical climate.

Limitation of study: This was a small study and thus observations, may not be generalizable to other settings. Data regarding the techniques employed in the application of sunscreens and to which sites of their body would have been informative.

This is a selected out population- its most likely albinos with complications that will report to UBTH

\section{CONCLUSION}

The sun protection patterns described by this study provide insight into the lives of persons living with albinism in this region, with implications for public health measures across the region. Empowerment of those living with albinism in Nigeria with the knowledge of the benefits of sun protection strategies is key in reducing the deleterious effects of the tropical sunshine in Nigeria. Protection from the sun must thus start at birth and continue throughout life.

Conflicts of interest: There are no conflicts of interest.

Acknowledgement: We also wish to appreciate every person living with albinism that consented to the study.

\section{REFERENCES}

1. Spritz RA. Detection of mutations in tyrosinase gene in a patient with type 1A oculocutaneous albinism. N Engl J Med 1990; 322:17224-28

2. King RA. Temperature sensitive tyrosinase associated with peripheral pigmentation in oculocutaneous albinism. J Clin Invest 1991; 87: 1046-53

3. Wei ML. Hermansky-pudlak syndrome: A disease of protein trafficking and organelle function. Pigment call Rev 2006; 19: 19-42

4. Venter PA, Christianson AL, Hutamo CM, MP M, GS G: Congenital anomalies in rural black South African neonates - a silent epidemic?. S Afr Med J. 1995, 85 (1): 15-20.

5. Lund P, Maluleke T, Gaigher I, Gaigher M: Oculocutaneous albinism in a rural community of South Africa: A population genetic study. Annals ofHuman Biology. 2007, 34 (4): 493-497.

6. Bothwell JE, Abs T: Pigmented skin lesions in tyrosinase-positive oculocutaneous albinos: A study in black South Africans. International Journal of Dermatology. 1997, 36 (11): 831-836.

7. Kromberg JG, Castle D, Zwane EM, Jenkins T: Albinism and skin cancer in Southern Africa. Clin Genet. 1989, 36(1): 43-52.

8. Yakubu A, Mabogunje OA: Skin cancer in African albinos. Acta Oncologica. 1993, 32 (6): 621-622.

9. Gaigher R, Lund P, Makuya E: A sociological study of children with albinism at a special school in the Limpopo province. Curationis. 2002, 25 (4): 4-11.

10. Luande J, Henschke C, Mohammed N: The Tanzanian human albino skin. Natural history. Cancer. 1985, 55 (8): 1823-1828. 
11. Preston D, Stern R: Nonmelanoma cancers of the skin. The New England Journal of Medicine. 1992, 327 (23): 1649-1662.

12. Okulicz JF, Shah RS, Schwartz RA, Janniger CK: Oculocutaneous albinism. Journal of the European Academy of Dermatology and Venereology. 2003, 17: 251-256.

13. Asuquo M, Agweye P, Ugare G, Ebughe G: Basal cell carcinoma in five albino Africans from the south-eastern equatorial rain forest of Nigeria. International Journal of Dermatology. 2007, 46 (7): 754-756.

14. Okoro A: Albinism in Nigeria. A clinical and social study. The British Journal of Dermatology. 1975, 92 (5): 485-492.

15. Lookingbill DP, Lookingbill GL, Leppard B. Actinic damage and skin cancer in albinos in northern Tanzania: findings in 164 patients enrolled in an outreach skin care program. Journal of the American Academy of Dermatology. 1995, 32 (4): 653-658.

16. Jekel JF, Elmore JG, Katz DL. Sample size, randomization and probability theory. Epidemiology, Biostatistics and Preventive Medicine. Philadelphia: Saunders; 1996; 159-71.

17. Snow ball sampling- Chain referral sampling. Available at explorable.com/snowball sampling (Cited on $29^{\text {th }}$ January 2014 at 23.50hrs)

18. Hong E, Zeeb H, Repacholi M: Albinism in Africa as a public health issue. BMC Public Health. 2006, 6 (1): 212-10.1186/1471-2458-6212 .
19. Taylor J, Lund P: Experiences of a feasibility study of children with albinism in Zimbabwe: A discussion paper. Int J Nurs Stud . 2008, 45 (8): 1247-1256.

20. Lund PM: Health and education of children with albinism in Zimbabwe. Health Education Research. 2001, 16(1): 1-7. 10.1093/her/16.1.1.

21. Kagore F, Lund PM. Oculocutaneous albinism among school children in Harare, Zimbabwe. Journal of Medical Genetics. 1995; 32:859-861

22. Adam J, Samdani I, Bahram K. A unique albino village of Bhatti tribe in rural Sindh, Parkistan, with occulocutaneous albinism manifestation. An epidemiological study. Iranian Journal of dermatology 2009; 12:2

23. Kromberg JG, Castle D, Zwane EM, Jenkins T: Albinism and skin cancer in Southern Africa. Clin Genet. 1989; 36:43-52.

24. Clydesdale G, Dandie H. Ultraviolet light induced injury: immunological and inflammatory effects. Immunology and cell biology 2001; 79(6):547-68.

25. Hanneman K, Cooper K, Baron E: Ultraviolet immunosuppression: mechanisms and consequences. Dermatologic Clinics. 2006, 24 (1): 19-25.

26. Naylor M, Farmer K. The case for sun screen.A review of its use in preventing actinic damage and neoplasia. Arch dermatol 1997; 33(90):1146-54.

27. Levy SB. How high is SPF?. Arch dermatol1995; 131(12):1463-4

How to cite this article:

Madubuko C.R., Onunu A.N. Sun-protection strategies amongst people living with Albinism in Benin-city, Southern Nigeria. Research Journal of Health Sciences, 2021, 9(3): 245-253 
Table 1: Sociodemographic data

\begin{tabular}{|c|c|}
\hline $\begin{array}{l}\text { Epidemiological } \\
\text { Parameter }\end{array}$ & $\begin{array}{l}\text { Albino } N=73 \\
n(\%)\end{array}$ \\
\hline \multicolumn{2}{|l|}{ Age } \\
\hline Mean \pm SD & $24.1 \pm 11.3$ years \\
\hline$=10$ years & $10(13.7)$ \\
\hline 11-20years & $17(23.3)$ \\
\hline $21-30$ years & $27(37)$ \\
\hline $31-40$ years & $15(20.5)$ \\
\hline $41-50$ years & $3(4.1)$ \\
\hline $51-60$ years & $1(1.4)$ \\
\hline \multicolumn{2}{|l|}{ Sex } \\
\hline Female & $41(56.2)$ \\
\hline Male & $32(43.8)$ \\
\hline \multicolumn{2}{|l|}{ Occupation } \\
\hline Unemployed & $43(58.9)$ \\
\hline Traders & $10(13.7)$ \\
\hline Healthcare workers & $6((8.2)$ \\
\hline Artisans & $6(8.2)$ \\
\hline Teachers & $4(5.5)$ \\
\hline Banker & $1(1.4)$ \\
\hline Lawyers & $1(1.4)$ \\
\hline Journalist & $1(1.4)$ \\
\hline Comedian & $1(1.4)$ \\
\hline \multicolumn{2}{|c|}{ Predominant activity type } \\
\hline In-door & $11(15.1)$ \\
\hline Out-door & $62(84.9)$ \\
\hline \multicolumn{2}{|l|}{ Marital Status } \\
\hline Married & $9(12.3)$ \\
\hline Separated & $1(1.4)$ \\
\hline Single & $63(86.3)$ \\
\hline \multicolumn{2}{|l|}{ Educational Status } \\
\hline None & $13(17.8)$ \\
\hline Primary & $3(4.1)$ \\
\hline Secondary & $12(16.4)$ \\
\hline Tertiary & $45(61.6)$ \\
\hline \multicolumn{2}{|l|}{ Monthly Income (N) } \\
\hline$<20,000$ & $48(65.8)$ \\
\hline 20,000 to 49,000 & $10(13.7)$ \\
\hline$=50,000$ to 99000 & $9(12.3)$ \\
\hline $100000-199000$ & $6(8.2)$ \\
\hline
\end{tabular}




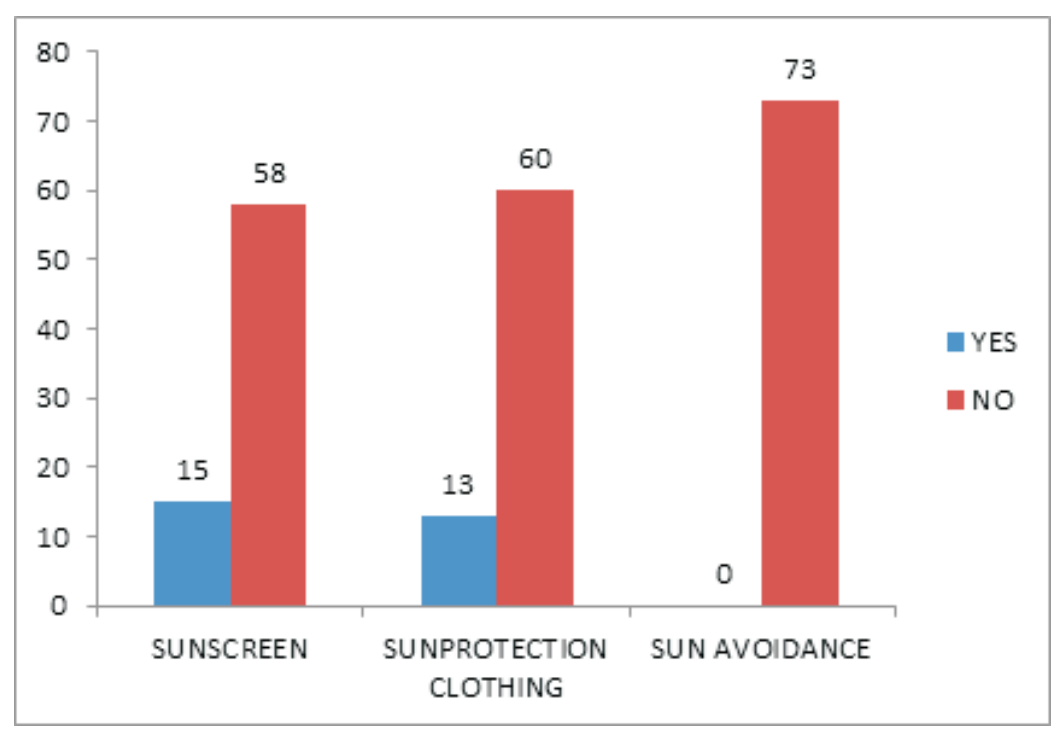

Figure 1: Frequency distribution of sun-protection methods used

Table 2: Relationship between sex and sun-protection methods

\begin{tabular}{llll}
\hline SEX & \multicolumn{3}{l}{ SUNSCREEN USE n(\%) } \\
& NO & YES & \\
\hline Female & $31(42.5)$ & $10(13.7)$ & $\mathrm{P}=0.267$ \\
Male & $27(37)$ & $5(6.8)$ & \\
& & & \\
& SUN-PROTECTION CLOTHING \\
Female & NO & YES & \\
Male & $24(49.3)$ & $5(6.8)$ & \\
& & & \\
& & & \\
& & & \\
\end{tabular}

Table 3: Relationship between age group and sun-protection methods

\begin{tabular}{|c|c|c|c|}
\hline \multirow[t]{2}{*}{ AGE GROUP } & \multicolumn{3}{|c|}{ SUNSCREEN USE n(\%) } \\
\hline & NO & YES & \\
\hline$=10$ years & $8(11)$ & $2(2.7)$ & $\mathrm{P}=0.308$ \\
\hline $11-20$ years & $16(21.9)$ & $1(1.4)$ & \\
\hline $21-30$ years & $18(24.7)$ & $9(12.3)$ & \\
\hline $31-40$ years & $12(16.4)$ & $3(4.1)$ & \\
\hline 41-50 years & $3(4.1)$ & $0(0)$ & \\
\hline $51-60$ years & $1(1.4)$ & $0(0)$ & \\
\hline \multirow[t]{3}{*}{ AGE GROUP } & \multirow{2}{*}{\multicolumn{3}{|c|}{$\begin{array}{l}\text { SUNPROTECTION } \\
\text { CLOTHING }\end{array}$}} \\
\hline & & & \\
\hline & NO & YES & \\
\hline$=10$ years & $9(12.3)$ & $1(1.4)$ & $\mathrm{P}=0.704$ \\
\hline $11-20$ years & $15((20.5)$ & $2(2.7)$ & \\
\hline 21-30 years & $20(27.4)$ & $7(9.6)$ & \\
\hline $31-40$ years & $13(17.8)$ & $2(2.7)$ & \\
\hline $41-50$ years & $2(2.7)$ & $1(1.4)$ & \\
\hline $51-60$ years & $1(1.4)$ & $0(0)$ & \\
\hline
\end{tabular}


Table 4: Relationship between educational status and sun protection methods

\begin{tabular}{llll}
\hline \multirow{2}{*}{ EDUCATIONAL STATUS } & \multicolumn{4}{l}{ SUNPROTECTION CLOTHING n(\%) } \\
& NO & YES & \\
\hline None & $12(16.4)$ & $1 .(1.4)$ & $\mathrm{P}=0.538$ \\
Primary & $3(4.1)$ & $0(0)$ & \\
Secondary & $10(13.7)$ & $2(2.7)$ & \\
Tertiary & $35(47.9)$ & $10(13.7)$ & \\
& & & \\
EDUCATIONAL STATUS & SUNSCREEN n(\%) & \\
& NO & YES & \\
None & $11(15.1)$ & $2(2.7)$ & $\mathrm{P}=0.374$ \\
Primary & $3(4.1)$ & $0(0)$ & \\
Secondary & $11(15.1)$ & $1(1.4)$ & \\
Tertiary & $33(45.2)$ & $12(16.4)$ & \\
\hline
\end{tabular}

Table 5: Relationship between predominant activity type and sun protection methods

\begin{tabular}{llll}
\hline ACTIVITY TYPE & \multicolumn{4}{l}{ SUNPROTECTION CLOTHING n(\%) } \\
& NO & YES & \\
\hline Indoor & $19(26)$ & $2(2.7)$ & $\mathrm{P}=0.538$ \\
Outdoor & $51(69.9)$ & $11(15.1)$ & \\
ACTIVITY TYPE & SUNSCREEN & $\mathbf{n}(\%)$ & \\
& NO & YES & \\
Indoor & $6(8.2)$ & $5(6.8)$ & $\mathbf{P}=\mathbf{0 . 0 4 *}$ \\
Outdoor & $52(71.2)$ & $10(13.7)$ & \\
\hline
\end{tabular}

